Journal of Critical Race Inquiry

Volume 4, Number 1 (2017) pp. 1-24

\title{
Whiteness in the Qualitative Research Setting: Critical Skepticism, Radical Reflexivity and Anti-racist Feminism
}

\author{
Katerina Deliovsky \\ Department of Sociology, Brock University
}

\begin{abstract}
This essay critically reflects on challenges and dilemmas I encountered when interviewing white women about their experiences with gender, racialization, and practices of whiteness. These challenges and dilemmas in the research setting relate to the researcherparticipant relationship and, in particular, participants' use of 1) a "rhetorical ethic," in which their social justice narratives were contradicted by demonstrations of their own racist ideologies; and 2) how whiteness and femininity were sites of power and resources for "social desirability bias" and impression management in response to my positionality as a white woman with a Black spouse and two racially mixed children. Additionally, this essay grapples with the emotionally difficult journey of being a researcher with the feminist commitment of "giving voice" to women by developing a bond of mutual trust, while at the same time feeling compelled to conceal oneself in search of "honest" responses from the research participants. This reflection illuminates how a/symmetries of power between researcher and the researched are inscribed with race and gender dynamics that are not always discernible, yet have a tremendous influence on data gathering. These dynamics require recognizing the agency of the research participants to shape what are considered and interpreted as data. These dynamics also require treating the data with "critical skepticism" and subjecting the participants' responses to a "radical reflexivity" rooted in understanding how the larger social, political and historical "facts of whiteness" inform the microcosm of the researcher-participant relationship.
\end{abstract}

Keywords: whiteness, anti-racist methodology, anti-racist feminism, critical skepticism, reflexivity. 


\section{Introduction}

This essay is a critical race and feminist reflection on the ethical and methodological dilemmas of racism I encountered in my research with white women who claim anti-racist and social justice identities, but, based on the research I conducted, appear to practice its opposite. I elaborate on the concepts of "critical skepticism" and "radical reflexivity" (Gunaratnam, 2003) as I reflect on what the interview context with white women might reveal about a) white racialized power in the research setting; b) ethics in feminist research; and c) strategies of reflexivity for resolving normative conflicts around racism between researcher and research participants. As such, this essay is situated in the critical race and feminist agenda that "prioritizes 'studying up' - studying the powerful, their institutions, policies and practices instead of focusing only on those whom the powerful govern" (Harding and Norberg, 2005, p. 2011). Until recently, for Western feminists at least, this meant studying men. From the inception of the Western feminist movement, women were predominantly theorized as a homogenous universally oppressed group - as if the hegemonic nature of patriarchy obliterated all differences between women and men vis-à-vis class, culture, race, and subjectivity. By the 1990s, largely through the critical insights of feminists of colour (see, for example, Beale, 1972; Collins, 1986; Davis, 1981; Dill, 1983; Hull, Bell-Scott and Smith, 1982; King, 1988; Moraga and Anzaldua, 1983) it could not be ignored that the foundations of dominant feminist epistemology and research were white-centred and mirrored the racial exclusionary practices and hierarchies found in society at large.

The unrelenting challenges posed by Black feminists and other critical feminists of colour called attention to the problematic conceptualization of equal oppression among all women. Rather, it was argued that women occupy different cultural, sexual, racial, and class locations and thus their experiences and consequently their standpoint would vary (Collins, 1990; King, 1988). These varying standpoints (Jaggar, 1983) necessitated an approach that attended to the contextual and historical intersections and realities of class, ethnicity, race, gender, and sexuality, among others (Brewer, 1999; Crenshaw, 1991; Dill, 1983). Moreover, critical race feminists argued that if feminism was to be an ethically humane and liberatory enterprise it must take seriously these interconnected inequities within social relations and, thus, within feminism itself (Bannerji, 1995; Mohanty, 2003). Countering the monistic hegemony of an undifferentiated womanhood, the appellation of "intersectionality" emerged

\footnotetext{
1 I use intersectionality here following Black feminist theorizing that posits understanding the "embeddedness and relationality of race, class and gender and the multiplicative nature of these relationships.” (Brewer, 1999, p. 16).
} 
to critique straight white middle class theorizing as well as, critically, to specify women's difference and relatedness (Brewer, 1999).

Taking "intersectionality" seriously, however, always meant more than theorizing race, class, and gender from the standpoint of women stigmatized by these inequities. It also aimed to explicate what Dorothy Smith calls the "concealed standpoint" (read: white standpoint) or "the position in the ruling relations that is taken for granted in how we speak and that bounds and constrains how a political economy of women can speak to women" (Smith, 1999, p. 43; see also Rowe, 2000). And if whiteness is contained and concealed within normative discourses on race and gender, then what research methods would contribute to an ethical enterprise that incorporates the voices of diverse groups of women while still ensuring a critical examination of this concealed standpoint? What, given the social stratifications between women, might the complexities of power look like in the research setting?

Others have attempted to answer these questions on ethics and power in the research setting. Daphne Patai (1991), for example, suggests that such an ethical enterprise might not be possible. She argues the potential for danger and exploitation in the research relationship always exists to favour the researcher at the participant's expense. This is assumed because as professional intellectuals, it is the researcher who structures the written document, interprets the words of the research participants and crafts a document to reflect their theoretical and methodological commitments. Patai (1991) asserts these elements of inequality and exploitation are inherent in the research relationship (see also Stacey, 1991). This exploitation is amplified when the research is cross-cultural and when "the researcher is interviewing 'down,' that is, among groups less powerful (economically, politically, socially) than the researcher herself" (Patai, 1991, p. 137). In the end, for Patai, feminist research may reproduce the very inequities and hierarchies it seeks to change. She asserts that, "in an unethical world, we cannot do truly ethical research" (Patai, 1991, p. 150). In this essay, I argue for an even more complex examination, one that specifically explores the power that research participants may possess and wield to shape the direction of the analysis of research data.

Patai's argument reflects the desire, particularly among feminist researchers, to understand the ways in which the social identity of the researcher (as raced, classed, and gendered beings) shapes the various stages of the research process. Of particular concern is the desire to protect the research participants from exploitation based on the presumed unequal power relationship between researcher and research participant (Collins, 1990; Harding, 1991; Oakley, 2000; Trinh, 1989). In confronting these issues, reflexivity and 
standpoint are offered as a way to open the research process to scrutiny and potentially mitigate exploitation (Collins, 1990; Harding, 1996; Hartsock, 1987). Others suggest that participatory action research with its commitment to participant involvement, action, and social change offers a way out (Naples, 1998). Others still suggest that a fusion of various theories and methodologies (such as Indigenous Methodology, Participatory Action Research and Whiteness Studies) can both honour research participants' narratives and challenge dominant epistemologies (Evans, Hole, Berg, Hutchinson, and Sookraj, 2009; Vaught, 2008).

Regardless of the theoretical and methodological orientations employed, feminist researchers are still left with the task of excavating how the concealed (or white) standpoint informs research principles, processes and practices. France Winddance Twine thinks it noteworthy that "after decades of self-reflexivity among ethnographers analyzing the practices of writing and conducting field research, [there remains a] lack of sustained attention to racialized dilemmas...[This is particularly troubling] considering the degree to which other axes of power have been theorized" (Twine, 2000, p. 5). Echoing a similar concern, Amy Best states: "whiteness as a particular racial location has only recently come under the critical researcher's gaze. Much work remains to be done in terms of excavating the terrain of whiteness as it relate[s] to qualitative research practices" (Best, 2003, p. 909; see also Gallager, 2000).

My research concerning white women and whiteness is situated in this context. It aims to help reconceptualise the foundation on which feminist activists participate in liberatory, humane, and antiracist work. The task is to make visible the positive racialization ${ }^{2}$ (Kitossa, 2004) of white women (their concealed standpoint) and its implications for how these women gain, administer, and negotiate power. To do this, I critically reflect on the methodological challenges and dilemmas that my research journey entailed. The research journey is as instructive of the power dimensions of whiteness as the actual data derived from the interviews and, as such, rests on the epistemological assumption that my methodological experience constitutes a source of knowledge (see Mauthner and Doucet, 2003). These challenges and dilemmas relate to some of the research participants': 1) gendered and raced instances of social desirability bias (Esterberg, 2001) and impression management (Goffman, 1959); 2) deployment of a "rhetorical ethic" (Ani, 1993); and 3) implicit commitment to racist ideologies.

\footnotetext{
2 As explained by Tamari Kitossa (2004) in a personal communication, positive racialization calls attention to the process of racialization that confers negative or positive attributes on to different groups of people. Whiteness, then, as a process of racialization, enables a "positive" signification and confers access, power and privilege to white people.
} 
I draw on these particular experiences because they help to illuminate how some of the complex power differences and similarities between researcher and the researched (who, in the case of my research, are both racial/gendered insiders and are white) are inscribed with race and gender dynamics. While other dynamics were present such as class, ethnicity, and sexuality; race and gender played dominant roles in this power dynamic. More specifically, these dynamics required me to rethink the power dimensions in the research relationship to recognize the agency of the research participants to shape what are considered and interpreted as data. These dynamics also necessitated that I treat the data with what I call "critical skepticism" and subject the participants' responses to a reflexivity rooted in understanding how the larger social, political, and historical "facts of whiteness" inform the research relationship. An integral part of this includes understanding how the research participants responded to my positionality as a white woman with a Black spouse and two racially mixed children. Linda McDowell (1992) writes that "we must recognize and take account of our own position, as well as that of our research participants, and write this into our research practice" (p. 409). This task was crucial because my positionality invariably and insidiously affected the interpersonal dynamic with my participants. Thus, this approach to reflexivity includes not only a process of conscious self-reflection on the part of the researcher, but also a deep understanding of the wider social context and power dynamics that can potentially shape the research process. This approach to reflexivity speaks to Yasmin Gunaratnam's (2003) call for a "radical reflexivity" that situates research as a part of social and historical relations rather than a simple reflection of what researchers are examining.

This call for reflexivity is certainly not new (Hammersley, 1984; Harding, 1991; Wasserfall, 1993) and has been a prominent issue in feminist and qualitative research. However, reflexivity, as is commonly understood in feminist standpoint (and in qualitative research more generally) is an obligation on the part of dominant researchers to rigorously theorize their subjective position as knowledge producers. Researchers are required to "gaze back" at their research as a socially situated project and explore the cultural assumptions that influence and historically situate it. Sandra Harding (1996) calls this "strong reflexivity" (see also DeVault, 1995; Fonow and Cook, 1991; Hertz, 1997). While potentially useful, this exercise has been limiting. Similarly to Gunaratnam, I found "making visible the social positioning of the researcher and research participant in relation to processes of interpretation and representation, is not enough to understand and address the complexities of difference"and sameness, I would add — as a white woman interviewing other white women. More specifically, this approach to reflexivity does not allow a critical understanding of how whiteness, as a mark of power, can affect the research relationship when researcher and 
participant are both racial and gender "insiders." The reason for this is because strong reflexivity, as with many discussions on reflexivity, fundamentally rests on the notion of an unequal power dynamic in the research relationship wherein the researchers holds most, if not all, of the power. Less attention has been paid in feminist qualitative research to the ways research participants do exercise power that modify the presumed absoluteness of the researcher's power during data gathering, data analysis, and interpretation (Blee, 1998; Bloom, 1991). Critical skepticism with a radical reflexivity, however, allows for a more complicated reading of power dynamics that occur in and outside the research relationship. This is important toward understanding not only the interactional and relational context of interviewing, but also how the researcher's and research participant's racial and gender identities are actively managed outside of the research setting and how this might enable unanticipated backstage disclosures (Goffman, 1959; Picca and Feagin, 2007).

Goffman's (1959) frontstage/backstage dramaturgical analysis provides a useful framework for considering the ways in which the research interview setting operates as a social performance between researcher and research participant. Goffman argues that, in an attempt to construct a positive self-image (i.e., frontstage), people will manipulate the impression they convey to strangers and acquaintances. This is in contrast to the backstage - a more private setting where people tend to find themselves among friends and relatives. Extending Goffman's analysis to how my research participants' social performances operate through a "racial frame" (Feagin, 2006; Picca and Feagin, 2007), I call attention to the subtle and insidious ways whiteness can function in the research setting. In focusing on whiteness, I draw on the invaluable work of critical race and feminist scholars who have contributed greatly toward understanding whiteness as a phenomenological issue (Ahmed, 2007), white racial framing (Feagin, 2006), white racial representation (Dyer, 1997), a location of structural advantage and a standpoint (Frankenberg, 1993), a membership process (Frye, 1992), property rights (Harris, 1993), and communication of social identity (Nakayama and Martin, 1999). As such, this essay contributes to the relatively newer methodological terrain that tries to attend to the "potential ethical, emotional, analytical and methodological dilemmas generated by racial [and gender] subjectivities [and] racial ideologies" (Twine, 2000, p. 5).

\section{The research participants: A brief overview}

In 2006 I conducted opened-ended interviews with 24 European Canadian women from southwestern Ontario, Canada. I primarily used purposive sampling to locate research participants. The 24 research participants included women from two groups: 12 women of 
northern and western European ancestry and 12 women of eastern and southern European ancestry. ${ }^{3}$ Within these two ancestral groupings were women from various socio-economic categories ranging from the unemployed working class, immigrant working class, working class, and middle class. The women's ages ranged from 17 to 70 years. Nine of these women were or had been in romantic relationships with men of African descent and two identified themselves as lesbians.

The broader questions that framed my research were as follows: What social contexts shape or work against European Canadian women's awareness of themselves as "white"? How do race, ethnicity, class, sexuality, and gender inform their senses of self and community? How do ethnicity, class, sexuality, gender, and race structure their experiences as "white" women? In what social contexts does "race" come into focus and how does this awareness affect their identity and social practices?

My reflection on this methodological journey rests on what transpired during that year of data gathering and data analysis. But more than this, subsequent years of journaling and distance from the emotional distress of the research setting has resulted in an appreciation of Mauthner and Doucet's (2003) argument that "data analysis is not a discrete and separate stage of the research process but rather ongoing throughout and beyond the life time of a project” (Mauthner and Doucet, 2003, p. 425; emphasis added).

\section{The methodological journey: Social desirability bias and impression management}

The race and gender dynamics of my research on white femininity resulted in an emotionally difficult journey for me, fraught with frustration. Possibly a function of women's socialization as unselfish caregivers - or perhaps a result of other reasons, which will be discussed hereafter - many of my research participants appeared overly concerned with making me happy. They provided the presumed socially acceptable answers and often "checked in." For example, after answering a question several research participants would then ask, "Is that what you wanted to hear? Did I say it how you wanted me to?" This response happened so frequently that I began giving a preamble that reassured the women that

\footnotetext{
${ }^{3}$ The women who were eastern or southern European had the following ancestry: four Italian, three Macedonian, one Italian \& Serbian, one Czech, one Polish, one Serbian and one Ukrainian. The women who were northern and western European had the following ancestry: five English, one French, one Irish, one Irish \& English, one German, one German \& Dutch, one Scottish, and one Scottish \& English. I grouped the women into these ancestral geographic/ethnic locations because they approximate the socially constructed hierarchy of whiteness between Europeans.
} 
I wanted to hear their "uncensored" thoughts and experiences. Yet, I was not convinced my reassurances worked. Their concern to give me the socially acceptable answer, identified as "social desirability bias"4 (Esterberg, 2001, p. 86), may have been shaped, in some ways, by gender and class socialization. These women, like most, are socialized to "take care" of other people's needs and thus may have responded to the questions by wanting to "take care" of me.

Their responses may have also been a result of collegial appreciation of the process of acquiring a doctorate. The women who most frequently exhibited this tendency were university educated and had some understanding of what sociologists study. In addition, the desire to give me the "right" answer may have been a result of deference to my position as researcher and the status and authority that results from that position. This position reflects some of the power imbalance in the research process; that is, the researcher and the participant are not on the same plane with respect, for example, to the written outcome of the work. Indeed, as Acker, Barry, and Esseveld (1991) suggest, it is difficult to avoid the position of researchers as those with the "power to define." Yet in the gathering of data, the distribution of power is far more complex and diffuse when we incorporate the participants' desire to manage their white social impression. Thus, even in writing up the data, the "power" of the researcher is as much perceived as it is real.

In addition to wanting to take care of me and provide me with the "right" answer, several women engaged in "impression management." During several interviews, impression management appeared to manifest, in particular, when exploring issues of race or when race became a salient issue in the interview context. While there were many examples and various degrees of (racialized) impression management, I draw on two specific experiences below. I draw on these two experiences because they are evocative of the challenges I confronted in my exploration of whiteness and white femininity.

I conducted some of my interviews in the sociology graduate student office, in which I had a desk. Approximately halfway through one particular interview I saw the research participant's eyes darting several times toward my desk. I realized the picture of my mixedrace children was drawing her attention. As she glanced over at the pictures a subtle shift occurred in how she answered the questions. I could feel, as it were, her "dis-ease." It was reflected in the change of her intonation, the pauses where there were none before, the darting

\footnotetext{
${ }^{4}$ Social desirability bias is a term most often applied to survey research to capture the phenomena of respondents giving a response they believe to be socially acceptable (Esterberg, 2002, p. 86); however, it can be applied to qualitative interviews.
} 
of her eyes to the picture and in her body language. Prior to the seeing the pictures, when the interview turned to the topic of white privilege she expressed concern for current "preferential" policies, such as affirmative action, which she believed made being white a disadvantage. She described a friend who was "trying to become a police officer, [however, she was experiencing] discrimination because she was a white woman." Adding to her "reverse discrimination" narrative she emphatically exclaimed "if you are a white male you can pretty much kiss your chances of getting into the police force good-bye." It was shortly thereafter that I noticed the pictures of my children catching her eye and both of us in that moment became conscious of race and how our whiteness no longer guaranteed a shared understanding of reality (Best, 2003). I made the decision thereafter to remove such memorabilia from subsequent interview settings. This is because I suspect that the fact that my children are of African and European ancestry and have the normative phenotypic expressions of Blackness affected how she answered my questions, particularly around issues of racial politics and whiteness. She appeared to adopt a liberal discourse of "not seeing colour and loving and accepting everybody" that was not evident prior to her seeing the pictures.

During another interview - after I had opted to remove the pictures of my children - a woman inquired about the "ethnic" background of my partner. In asking that question, I knew she assumed my spouse was "white" and, remembering my previous interview, I explained to her that I would disclose my partner's "ethnicity" after the interview. She seemed quite perplexed but was willing to wait. At the end of the interview she excitedly asked "Okay, spill it. What is your spouse's ethnicity?" I informed her that my partner is Jamaican Canadian of African heritage. A look of surprise and then horror moved across her face. She blurted out "Oh my God did I say anything to offend you?" Immediately after that statement she expressed regret in describing some of the racist comments she had heard. She said, "Oh no. I shouldn't have told you about the police constable," referring to a conversation she relayed during the interview that she had about racial profiling with a high-ranking white police constable. She had explained that this officer believed Jamaicans should be racially profiled because in his mind they did, indeed, commit more crimes. Her expression of regret indicated that had she known my partner's background before the interview she might not have told me the story. These experiences also suggested that, in order to get more honest responses from my research participants, I would need to keep my personal life private, at least prior and during the interviews.

It would be far too simplistic to argue that these women are racists and were simply disguising their racism; at the same time, racism has many nuanced expressions. Theories of 
"everyday racism" (Essed, 1991), “implicit bias" (Staats, 2016), "democratic racism" (Henry, 2000) and so on apprehend Joel Kovel's (1970) prognosis that white racism will increasingly morph from overt, to aversive, to metaracism - a process by which policies and institutional practices of racial exclusion obviate the necessity for conscious processes of investment in both intentional and obvious individual racial bias. What Kovel described now seems increasingly pertinent as the era of colour-blind racism emerges (Bonilla-Silva, 2006) and, as a result, racialized gendered contexts are far more complex to apprehend. Ruth Frankenberg (1993) argues that "white women have to repress, avoid, and conceal a great deal in order to maintain a stance of 'not noticing' color" (p. 35). This colour blindness - or what Frankenberg calls a "colour- and power-discourse" (p.189) — is a key feature in the "power relations of racism" (p. 30) and is central in constructing a "white self innocent of racism" (p. 188). My interviews were infused with these racialized power relations and it became evident that many participants were invested in constructing themselves as free of racism. The important point here, though, is that some of the women, once discovering my positionality, were not and might not have been forthright on their perspectives of race and whiteness.

These experiences are not peculiar to my research. Deirdre A. Royster (2003) in Race and the Invisible Hand: How White Networks Exclude Black Men from Blue Collar Jobs expressed similar concerns in her study. She writes,

conversation management, with its intricate codes, euphemisms, and censoring, is connected to the desire of most [white North] Americans to appear colorblind, or racially neutral, particularly when they are observed by someone they consider a racial "other" This pattern makes it difficult for researchers who conduct cross-racial interviews to be certain that their informants are not adjusting their responses in order to seem as much like completely unprejudiced beings as possible. (Royster, 2003, p. 3) While my interviews were not cross-racial, Royster's argument has application for my samerace interviews because the knowledge that my partner is Jamaican Canadian could/did influence the participants' responses. My racial identity as a white woman became "spoiled" by the transferred negative social stigma (Deliovsky, 2010) of my children and partner and, as such, the "sanctity" of whiteness was no longer guaranteed. Drawing on Goffman's frontstage/backstage analysis, Picca and Feagin in "Two-Face Racism: Whites in the Backstage and Frontstage" (2007) argue that "white" skin functions like a racial "passport" into the backstage where safe racialized performances occur with people of the same racially defined (usually white) group. Most white people guard the boundaries of the backstage; however, when there is "slippage" between the frontstage and backstage, this can result in a "spoiled performance." Picca and Feagin explain that, "[i]n the event of a spoiled 
performance, remedies must be made, such as performing a new role fit for the intruder, or offering an aligned action or verbal remark" (Picca and Feagin, 2007, p. 23). In this research context I was the white intruder (or race traitor) who spoiled the backstage arena as a safe racial space where my white participants did not need to "impression manage" and could let their proverbial (white) hair down. And so, in an ironic twist it became important that I, too, manage the impression I created for these women so that I might garner "honest" responses.

My impression management, however, was a difficult balancing act. This was for several reasons. One reason related to my feminist commitment of "giving voice" to women by developing a bond of mutual trust (rapport). This necessitated creating a comfortable atmosphere where the women could speak openly about their perceptions and experiences. As such, I needed to ensure I did not come across as a disinterested sociologist, but rather a warm sympathetic "observer." But how was I to be warm and sympathetic when I was intentionally surreptitious (Frankenberg, 1993)? How could I be "authentic" when my participants" behaviours were enabled by the systemic racism that routinely injured my family?

Needing to conceal my politics and personal life created a tension and strain that was frustrating and emotionally exhausting. It was also very unsettling because my response represented what Frankenberg describes as a necessary "withdrawal from the [hegemonic] feminist goal of sharing power by sharing information" (Frankenberg, 1993, p. 34). There I was, proclaiming myself an anti-racist feminist sociologist, committed to a liberatory politic, and yet, at the same time, I was concealing myself from the research participants. But, could it have been otherwise since not all of the women were, to use a feminist slogan, "sisters in the struggle"? It became apparent that if I wanted the research participants to speak as uncensored as possible they could not know certain details of my intimate life, nor my own anti-racist politics. Thus, I needed to modify some of the feminist methodological principles governing positionality and relational and emotional dynamics of disclosure and empathy building between researcher and participant.

Modifying these principles meant appreciating Kathleen Blee's (1998) assertion that emotions in qualitative research are not necessarily an "individual reaction or affectional state," but are rather a "negotiated and relational" experience between researcher and participant (p. 395). She states that, "just as researchers may try to [create] emotional dynamics of rapport [that] facilitate data collection in interviewing situations, so too respondents may attempt to create emotional dynamics that serve their strategic interests" (Blee, 1998, p. 395). The vital point here is that research participants, in creating emotional dynamics that serve their strategic interests, can and do exercise power in ways that modify the presumed absoluteness of the researcher's power. This exercise of power was particularly 
manifest in my experience with the "rhetorical ethic" of my research participants, or the often contradictory words and actions of my research participants. I now turn to this experience.

\section{The methodological journey and "rhetorical ethic"}

As mentioned, the race and gender dynamics in this research resulted in an emotionally difficult journey fraught with frustration. It, however, also resulted in a deepening cynicism about some participants' hidden commitments to racist (and sexist) ideologies. I was most struck and disturbed by some of the women's displays of what I now identify as a "rhetorical ethic" (Ani, 1993). Borrowing from Marimba Ani, rhetorical ethic is meant to capture what she argues is a strong current of Western European cultural imperialism, or "the confounding of meaning and commitment with mere verbal expressions...for the purposes of manipulation" (Ani, 1993, p. 313-314). This manipulation, according to Ani, rests on the desire of white colonials subject to project an image of themselves as the person they wish to appear (i.e., non-racist, progressive) rather than who they really are (i.e., committed to racial ideologies). The contradiction between superficial appearance and actual commitment, "between what people say and what they do" (p. 315) is a key feature of the rhetorical ethic. This rhetorical ethic was displayed by three of the research participants (that I was aware of) and was exhibited when they verbalized a progressive anti-racist feminist rhetoric during the interviews, yet participated in racist and sexist behaviour that I accidentally witnessed outside of the interview setting.

During the interviews, all three women appeared to be honest and actively engaged in the discussions on issues of white power and privilege. They appeared to be cognizant of some of the social contexts when "race" came into focus for them and how this awareness affected their identity and social practices. For example, one of the research participants commented that her race cognizance was a result of her university education. She said:

Looking at the literature through women studies and sociology...I see how whiteness exists in day to day exchanges and interaction, whether it is waiting for a bus, doing grocery shopping...particularly in service related exchanges I am now very cognizant of myself as a white person in academia....For example, who is it that cleans these

institutions. Who goes to these institutions and who teaches in these institutions? This research participant's awareness of white racial privilege is not unique to her. The other two participants I discuss in this section made similar comments. All three, in fact, constructed themselves as critical feminists who abhorred all forms of racism and sexism. Yet, 
a few weeks following the interviews I accidentally witnessed these women participating in the dissemination of racially and sexually offensive images of both Black men and Black men having sex with obese white women. I also learned that these women attempted to keep the dissemination of these images from me because at that point my partner's social identity as Jamaican Canadian was known. When asked directly asked why they kept the images hidden from me, they remarked, "We thought you might be offended." Indeed, I was offended. The stark contradiction between the narratives of these women and how they wished to be seen versus their behaviour, which was both racist and sexist, illustrated their investment in Ani's (1994) "rhetorical ethic." But, it also presented a dilemma-since they seemed to have little or no moral discomfort in espousing a commitment to anti-racism and feminism while practicing the opposite - what should I do with their interviews?

Had I not accidentally witnessed their "backstage" behaviour outside of the interview setting, I would never have known of their actual raced and gendered commitments. So unsettling was this serendipitous witnessing of the rhetorical ethic that I agonized about whether and how to write about it without betraying the confidence of my research participants. On one hand, if I included this observational experience as "data" the women could legitimately claim this disclosure is a betrayal of confidence. They had consented to be interviewed and so to use any conservation and data observed outside the research context raised serious ethical questions about confidentiality. Yet, on the other hand, entirely concealing their racist and sexist practices would result in a distortion of "truth."

After much thought, I decided on a highly abbreviated detailing of the incident. Considering that the accidental viewing and knowledge of their behaviour were not part of the interviews, I felt I had an ethical obligation to leave the details out of the data analysis. Moreover, providing details of the incident, such as descriptions of the images, in what context they occurred, the interactions that transpired around the dissemination of these images etc., cannot be provided without compromising the participants' identities and as such, confidentiality could not be guaranteed. In my write-up, therefore, I chose to conceal these actual details and to make oblique references to it by elaborating the concept of "rhetorical ethic."

The women's behaviour was disturbing, to say the least. How many others shared the same racist/sexist sentiments yet hid them from me? Picca and Feagin argue that whites tend to have "two faces" when it comes to their racial views, commentaries, and actions. They frequently present themselves as innocent of racism in the frontstage, indeed as "colorblind," even as they clearly show their racist framing of the world in their backstage, comments, emotions and actions. (2007, p. 19) 
And so, I will never know. However, these experiences reveal it is important to explore not only how racialized power relations of whiteness are reproduced by and in the everyday lives of our research participants, but also how they may be reproduced in and outside the research setting (Best, 2003).

Knowledge of the three participants' rhetorical ethic and impression management confirms that oral testimony, or self-reporting, cannot be analysed unproblematically (Naples, 2003; Reay, 1996). My research participants' contradictory behaviour revealed some of the limitations/challenges of using oral testimony through in-depth interviews with people from the dominant racial/gender group. When the researcher-researched are positioned on a relatively equal plane of social power, and especially where research participants retain the power of self-presentation, the feminist methodological principles of disclosure and empathy building may need to be problematized. My insider status, as both white and female, did not guarantee an honest and open rapport with these participants. Charles Gallagher, in "White Like Me? Methods, Meaning, and Manipulation in the Field of White Studies" warns that in the research setting being white "has a host of contradictory, symbolic, and situationally specific meanings" (2000, p. 10). As such, these meanings necessitate a radical reflexivity that positions the research participant not just as a powerless individual in the research process, but as an active member of and a window into a larger and complex social, cultural, and political system of racial privilege and marginalization (Vaught, 2008); this includes the research relationship itself. And while I was mindful going into the interviews that women from the dominant racial group may be complicit in everyday practices of what Dorothy Smith calls "relations of ruling" (given my interest in anti-racist and critical race feminism), I never imagined that they might also consciously be active in reproducing these relations in the interview relationship. What my experiences suggested (or screamed) was that I needed a different way to think through the raced/gender power dynamics in my research than was typically posited by feminist approaches on reflexivity - one that was better able to capture how power shifts and emotional labour (Hoffman, 2007) in the interview setting affect the raced/gendered interactional and contextual relations of research.

Speaking to this need, Amy Best (2003) argues that in working towards understanding the social relations of research itself, "the task for the qualitative researcher, feminist or otherwise... [is] active attention to the contextual organization of racial identities and racialized

\footnotetext{
${ }^{5}$ Dorothy Smith refers to relations of ruling as "a complex of organized practices including government, law, business and financial management, professional organization, and educational institutions as well as the discourses in text that interpenetrate the multiple sites of power" (Smith, 1987, p.3).
} 
talk. This means understanding that as we do research, we are also actively doing race" (p. 907). Clearly, my research participants (and I) were actively doing race and gender and performing the larger social political and historical narratives of whiteness in the interviews I conducted. Research on whiteness has shown that European descended people, even those who were at one time excluded from the benefits of whiteness, are heavily invested in constructing a "white" identity (Brodkin, 1998; Frankenberg, 1993; Moon, 1999; Roediger, 1994). Part of this investment is to be seen as "white" and to get the benefits accruing from that distinction; but, it is also to disguise or manage participation in a process of positive racialization, thereby evading white guilt and acknowledgement of complicity with white supremacy. As such, my research experiences suggest that researchers must not only be aware of social desirability bias, which assumes that the powerfulness of the researcher can "spoil" data, but that they must also be mindful that in crafting a "frontstage" (Goffman, 1959) persona, white research participants exercise power through a rhetorical ethic and impression management in ways that can also "spoil" the data. Considering the participants" investments in maintaining extant relations of ruling, be it intended or otherwise, I realized I needed to treat the participants' responses with what I call "critical skepticism."

\section{Critical skepticism and questions of power}

Critical skepticism ${ }^{6}$ involves subjecting the participants' responses and behaviour to an intellectual rigour rooted in understanding that raced and gendered dynamics, in concert with other possible ruling relations, are always at play in self-presentation. Recall Amy Best's argument that "the task for the qualitative researcher...[is] active attention to the contextual organization of racial identities and racialized talk" (Best, 2003, p. 907). Critical skepticism, then, is the "active attention to the contextual organization of racial identities and racialized talk." Of course, gender must be elaborated within this "contextual organization." As such, "active attention" to how the social organization of these subjectivities impacts the researcher and participant relationship can aid in a "truer" distillation of data. To ignore these dimensions as feminist researchers, Best warns us, "[can] distort how research relations resecure relations of domination even in the cases when research makes visible these relations but also constructs them anew" (2003, p. 910). Thus, critical skepticism offers a critical mode of radical reflexivity that attempts to capture the truly complex relationship between the

\footnotetext{
${ }^{6}$ My conceptualization of critical skepticism does not follow in the positivist footsteps of scientific or empirical skepticism which seeks reliability using the scientific method.
} 
participants and the researcher. It also offers a way to rethink how we understand research participants' positionality and power in the interview context. Nancy Naples (2003) argues that "research subjects have the power to influence the direction of the research, resist researchers' efforts and interpretations, and add their own interpretations and insights" (p. 4). This was certainly true of my research. As such, the belief that the researcher has what Leslie Bloom calls "The Power" over the research participant "is [constitutive of] an authoritative [and] binary discourse" (Bloom, 1993, p. 34) that functions to disguise the multiple ways power flows. Conceptualizing power dynamics in the research process in these terms is, therefore, problematic and needs to incorporate how power is also negotiated and manipulated through impression management and various other techniques.

Further to this, understanding how power is manipulated and negotiated necessitates understanding that participants' oral testimony does not inherently provide the raw data and experiences from which to draw one's conclusions. As Mary Maynard (1993) points out, there is no such thing as raw experience or data. Women's recollections of their experiences are "culturally embedded" (Maynard, 1993, p. 23) and as such their recollections are not only descriptions but also interpretations of them. As interpretations, their recollections reflect the participants' individual commitments to public and personal ideologies rather than authentic and accurate data (Giles, 2002); or, in the words of Goffman (1959), it can reflect their frontstage persona. These points need to be emphasised and are particularly relevant in the research contexts where whiteness can disguise the interactional and contextual relations between research participant and researcher.

\section{Conclusions: Where to From Here?}

The points raised in this essay underscore the need to continually explicate the actual practices in which feminist researchers are active. Dorothy Smith states that "exploring how sociology is assembled and organized as actual practices in which we too participate and by which our practices too are organized, we are also engaged in a reflexive examination and critique of what we know how to do" (Smith, 1999, p. 49). A reflexive examination and critique means rethinking the methodological and conceptual tools used to capture the complexity of power dynamics in the researcher-participant relationship. In my research, this re-examination necessitated a critical skepticism and a radical reflexivity that problematized feminist methodological principles that insist researchers' honour and respect their research participants while capturing data that produces knowledge to challenge oppressive relations. Again, I needed to problematize those principles because how does one "honour" research 
participants who display a rhetorical ethic, engage in impression management and, in some cases, are racist?

On a concluding note, Sabina Vaught (2005) offers an interesting perspective to the ethical concern of doing radical research with racist participants. She argues that such research requires "relational responsibility, through the frame of political race" (Vaught, 2005, p. 568). She explains that "relational responsibility," conceptualized by Clandinin and Connelly (2000), attempts to identify the parameters of ethical research. Clandinin and Connelly's argument is that participants' narratives, while fruitful for the research agenda, must not "cause shame or humiliation if they [are] shared...[I]t is the relational responsibility of the researcher to exercise discretionary judgement and withhold those particular narratives" (as cited in Vaught, 2005, p. 568). The impetus here is to "honour" the interactional dynamic between researcher and the research participants above research goals. Problematizing and extending this argument, Vaught contends relational responsibility that gives primacy to individual research participants "is restrictive and potentially reifies a positivistic, universalist, dominant epistemological stance, particularly when that participant actively asserts racial dominance" (Vaught, 2005, p. 570). She suggests that to avoid reinscribing this dominant stance, relational responsibility must not be rooted in individualistic notions of ethical responsibility; rather, it be directed toward radical social transformation and situated as a responsibility and "accountability to collectives and to the dynamic system that affect[s] collective, cultural experience" (Vaught, 2005, p. 578). Vaught further argues for accountability to a collective for the purpose of social justice, and calls on linking relational responsibility to what Guinier and Torres (2002) call "political race" (Guinier and Torres, 2002; as cited in Vaught, 2008, p. 577). Political race requires the researcher to line up their research with "those for whom they seek social justice...[and] asks the...researcher to be an activist, not just a collector, and to conceive of narrative as an act rather than anject' (Vaught, 2008, p. 578; italics in the original).

Appreciating Vaught's attempt to both honour the research participant and analyse their narratives for an understanding of systemic racism, I am persuaded to re-analyse my research dilemmas with this methodological directive. My "relational responsibility" to the participants who displayed a rhetorical ethic required that I omit the details of their racist actions because they occurred outside the interview structure and could potentially compromise their confidentiality. "Political race," however, compelled me to examine how their rhetorical ethic and attempts at impression management drew on cultural discourses that reinscribed master narratives of race and gender. Putting "relational responsibility" above my commitment to radical feminist research would have rendered me unable to fully appreciate 
how knowledge production and research relationships are "socially situated" activities (Fontana and Frey, 2008, p. 145) in which the research participants have power over their presentation of self.

Recall Haraway's (1991) assertion that knowledge production must always be understood as situated in a particular context and location. In this regard, a research participant can best be understood as "actor and agent" in the production of knowledge. Haraway contends that "coming to terms with the agency of the 'objects' studied is the only way to avoid gross error and false knowledge... in [the] sciences" (Haraway, 1991, p. 198). My participants are, as are all others, both actor and agent in their "strategic interest" seeking to craft a particular image and impression of their identity. Thus to reiterate, doing feminist qualitative research should not be an abstract endeavour but, rather, an engaged process that is radically reflexive.

Finally, a note of caution is necessary here. Suzanne Day (2012) points out that reflexivity is not a magic cure for methodological dilemmas. She states: "One thing that is clear...is that qualitative methodology in its complex entirety, and the kinds of qualitative accounts we produce, may simultaneously benefit from and be constrained by ones' particular approach to reflexivity" (Day, 2012, p. 80). Her point is well taken and, with this in mind, this approach to reflexivity includes not only a process of conscious self-reflection on the part of the researcher, but also a deep understanding of the wider social context and power dynamics that can potentially shape the research process. Day cogently argues that " $\mathrm{t}] \mathrm{o}$ limit ourselves to an understanding of power solely within the interactional context renders us unable to consider the full extent to which power may pose dilemmas in all relevant aspects of qualitative research" (Day, 2012, p. 66). As such, critical skepticism is an approach to reflexivity that radically positions the research participant not as a powerless individual in the research process, but as an "actor and agent" in a larger social context marked by gendered racial privilege and marginalization.

For me to have conceptualized power primarily as discrete interactional dynamic between researcher and participant would have obscured the ways that whiteness, race and gender were not only constituted in the research relationship, but also how that relationship is constituted by larger social, political, and historical forces. Failing to address this dynamic would have rendered unintelligible the connection between race and gender in the research relationship as well as obfuscate the complex ways that the power and privileges of whiteness manifest in the research context. Ultimately, I suggest feminist researchers committed to doing social justice through ethical research may well consider critical skepticism and radical 
reflexivity as useful practices and philosophical antidote to the problems of research in a hegemonically unethical world.

\section{References}

Acker, J., Barry, K., \& Esseveld, L. (1991). Objectivity and truth: Problems in doing feminist research. In M. M. Fonow, \& J. A. Cook (Eds.), Beyond Methodology (pp. 133-153). Bloomington: Indiana University Press.

Ahmed, S. (2007). A phenomenology of whiteness. Feminist Theory, 8(2), 149-168.

Ani, M. (1994). Yurugu: An African-centered critique of European cultural thought and behaviour. New Jersey: Africa World Press.

Atkinson, P., \& Hammersley, M. (1994). Ethnography and participant observation. In N.K. Denzin, \& Y. S. Lincoln (Eds.), Handbook of Qualitative Research (pp. 248-260). Thousand Oaks, CA: Sage Publications.

Bannerji, H. (1995). Thinking through: Essays on feminism, Marxism and anti-racism. Toronto, ON: Women's Press.

Beale, Frances. (1970). Double Jeopardy: To be Black and Female. In T. C. Bambara (Ed.), The Black Woman: An Anthology. Toronto: New American Library of Canada Ltd.

Best, A. (2003). Doing race in the context of feminist interviewing: Constructing whiteness through talk. Qualitative Inquiry, 9(6), 895-914.

Blee, K. (1998). White-knuckle research: Emotional dynamics in fieldwork with racist activists. Qualitative Sociology, 21(4), 381-399.

Bloom, L. (1998). Under the sign of hope. Feminist methodology and narrative interpretation. Albany, NY: State University of New York Press.

Bonilla-Silva, E. (2006). Racism without racists: colour-blind racism and the persistence of racial inequality in the United States. Lanham, MD: Rowman \& Littlefield, Inc.

Brewer, R. M. (1999). Theorizing race, class and gender: The new scholarship of black feminist intellectuals and black women's labor. Race, Gender \& Class, 6(2), 29-47.

Brodkin, K. (1998). How Jews became white folks and what that says about race in America. New Brunswick, NJ: Rutgers University Press.

Clandinin, D. J. \& Connelly, M. (2000). Narrative inquiry: Experience and story in qualitative research. San Francisco, CA: Jossey-Bass.

Collins, P. H. (1986). Learning from the outsider within: The sociological significance of Black feminist thought. Social Problems, 33(6), 14-32. 
Collins, P. H. (1990). Black feminist thought: Knowledge, consciousness, and the politics of empowerment. Boston, MA: Unwin Hyman.

Crenshaw, K. (1991). Mapping the margins: Intersectionality, identity politics, and violence against women of color. Stanford Law Review, 43(6), 1241-1299.

Davis, A. (1981). Women, race, and class. New York, NY: Random House

Davy, K. (1995). Outing whiteness. Theatre Journal, 47, 189-205.

Day, S. (2012). A reflexive lens: Exploring dilemmas of qualitative methodology through the concept of reflexivity. Qualitative Sociology Review, 3(1), 60-84.

Deliovsky, K. (2010). White femininity: Race, gender and power. Black Point, NS: Fernwood Publishing.

DeVault, M. L. (1995). Ethnicity and expertise: Racial-ethnic knowledge in sociological research. Gender \& Society, 9, 612-631.

Dill, B. T. (1983). Race, class and gender: Prospects for an all-inclusive sisterhood. Feminist Studies, 9(1), 131-150.

Dyer, R. (1997). White. London, UK: Routledge.

Essed, P. (1991). Understanding everyday racism: An interdisciplinary theory. Newbury Park, CA: Sage Publications.

Esterberg, K. G. (2001). Qualitative methods in social research. Boston, MA: McGraw Hill.

Evans, M., Hole, R., Berg, L. D., Hutchinson, P., \& Sookraj, D. (2009). Common insights, differing methodologies: Toward a fusion of indigenous methodologies, participatory action research, and white studies in an urban Aboriginal research agenda. Qualitative Inquiry, 15(5), 893-910.

Feagin. J. R. (2006). Systemic racism: A theory of oppression. New York, NY: Routledge.

Finlay, L. (2002). Negotiating the swamp: The opportunity and challenge of reflexivity in research practice. Qualitative Research, 2(2), 209-230.

Fonow, M. M., \& Cook, J. A., (Eds.). (1991). Beyond methodology: Feminist scholarship as lived research. Bloomington, IN: Indiana University Press.

Fontana, A., \& Frey, J. H. (2008). The interview: From neutral stance to political involvement. In N.K. Denzin and Lincoln, Y.S. (Eds.), Collecting and interpreting qualitative materials (pp. 115-160). Thousand Oaks, CA: Sage Publications.

Frankenberg, R. (1993). The social construction of whiteness: White women, race matters. Minneapolis, MN: University of Minnesota Press.

Frye, M. (1992). Willful virgin: Essays in feminism, 1976-1992. Freedom, CA: The Crossing Press. 
Gallagher. C. (2000). White like me? Methods, meaning, and manipulation in the field of white studies. In F. W. Twine, \& J. W. Warren (Eds.), Racing research, researching race: Methodological dilemmas in critical race studies (pp. 67-92). New York, NY: NYU Press.

Giles, J. (2002). National countermemories: Narratives of gender, class, and modernity in women's memories of mid-twentieth century Britain. Signs: Journal of Women in Culture and Society, 28(1), 21-41.

Goffman, E. (1959). The presentation of self in everyday life. New York, NY: Anchor Doubleday.

Guinier, L., \& Torres, G. (2002). The miner's canary: Enlisting race, resisting power, transforming democracy. Cambridge, MA: Harvard University Press.

Gunaratnam, Y. (2003). Researching 'race' and ethnicity: Methods, knowledge and power. London, UK: Sage Publications.

Hammersley, M. (1984). The research exposed: A natural history. In R. Burgess (Ed.), The research process in educational settings: Ten case studies (pp. 39-67). Lewes, UK: Falmer Press.

Haraway, D. J. (1991). Simians, Cyborgs and Women. New York, NY: Routledge.

Harding, S. 1991. Whose science? Whose knowledge?: Thinking from women's lives. New York, NY: Cornell University Press.

Harding, S. (1996). Rethinking standpoint epistemology: What is 'strong objectivity?' In E. F. Keller, \& H.E. Longino (Eds.), Feminism and science (pp. 235-48). Oxford, UK: Oxford University Press.

Harding, S., \& Norberg, K. (2005). New feminist approaches to social science methodologies: An introduction. Signs: Journal of women in culture and society, 30(4), 2009-2015.

Harris, C. (1993). Whiteness as property. Harvard Law Review, 106, 1707-1752.

Hartsock, N. (1987). The feminist standpoint: Developing the ground for a specifically feminist historical materialism. In S. Harding (Ed.), Feminism and methodology (pp. 157-180). Bloomington, IN: Indiana University Press.

Henry, F. (2000). The colour of democracy: Racism in Canadian society. Toronto, ON: Harcourt Brace Canada.

Hertz, R. (1997). Reflexivity and voice. Thousand Oaks, CA: Sage Publications.

Hoffmann, E. A. (2007). Open-ended interviews, power, and emotional labor. Journal of contemporary ethnography, 36(3), 318-346.

hooks, b. (1984). Feminist theory: From margin to center. Boston, MA: South End Press. 
Hull, G., Bell-Scott, P., \& Smith, B. (1982). All the women are white, all the blacks are men, but some of us are brave: Black women's studies. New York, NY: Feminist Press.

Jaggar, A. (1983). Feminist politics and human nature. Totawa, NJ: Rowman \& Allanheld.

King, D. (1988). Multiple jeopardy, multiple consciousnesses: The context of a Black feminist ideology. Signs: Journal of women in culture and society, 14(1), 42-72.

Kitossa, T. (2004). Personal Communication.

Kovel, J. (1970). White racism: A psychohistory. New York, NY: Pantheon Books.

Lumsden, K. (2009). “Don’t ask a woman to do another woman's job": Gendered interactions and the emotional ethnographer. Sociology, 43(3), 497-513.

McDowell, L. (1992). Doing gender: Feminism, feminists and research methods in human geography. Transactions, Institute of British Geographers, 17, 399-416.

McIntosh, P. (1990). White privilege: Unpacking the invisible knapsack. Independent School, Winter, 31-36.

Mauthner, N. S., \& Doucet, A. (2003). Reflexive accounts and accounts of reflexivity in qualitative data analysis. Sociology, 37(3), 413-431.

Maynard, M. (1994). Methods, practice and epistemology: The debate about feminism and research. In M. Maynard, \& J. Purvis (Eds.), Researching Women's Lives from a Feminist Perspective (pp. 10-27). London, UK: Taylor \& Francis.

Mohanty, C. (2003). Feminism without borders: Decolonizing theory, practicing solidarity. Durham, NC: Duke Press.

Moon, D. (1999). White enculturation and bourgeois ideology: The discursive production of "good (white) girls." In T. Nakayama, T., \& J. Martin (Eds.), Whiteness: The social communication of social identity (pp. 177-197). Thousand Oaks, CA: Sage Publications.

Moraga, C., \& Anzaldúa, G. (1983). This bridge called my back: Writings by radical women of color. New York, NY: Kitchen Table, Women of Color Press

Nakayama, T., \& Martin, J. (1999). Whiteness: The social communication of social identity. Thousand Oaks, CA: Sage Publications.

Naples, N. (1998). Community activism and feminist politics: Organizing across race, class, and gender. New York, NY: Routledge.

Naples, N. (2003). Feminism and method: Ethnography discourse analysis and activist research. New York, NY: Routledge.

Oakley, A. (2000). Experiments in knowing: Gender and method in the social sciences. New York, NY: The New Press. 
Patai, D. (1991). U.S. academics and third world women: Is ethical research possible? In S. Gluck, \& D. Patai (Eds.), Women's words: The feminist practice of oral history (pp. 137-153). New York, NY: Routledge.

Picca, L. H., \& Feagin, J. R. (2007). Two-faced racism: Whites in the backstage and frontstage. New York, NY: Routledge.

Reay, D. (1996). Insider perspective or stealing the words out of women's mouths: Interpretation in the research process. Feminist Review, 43, 57-73.

Roediger, D. (1994). Towards the abolition of whiteness: Essays on race, politics and working class history. New York, NY: Verso.

Rowe, A. C. (2000). Locating feminism's subject: The paradox of white femininity and the struggle to forge feminist alliances. Communication Theory, 10(1), 64-80.

Royster, D. (2003). Race and the invisible hand: How white networks exclude black men from blue-collar jobs. Berkeley, CA: UC Press.

Shome, R. (2010). Diana and beyond: White femininity, national identity, and contemporary media culture. Chicago, IL: University of Illinois Press.

Smith, D. (1987). The everyday world as problematic. A feminist sociology. Toronto, ON: University of Toronto Press.

Smith, D. (1999). Writing the social: critique, theory, and investigations. Toronto, ON: University of Toronto Press.

Song, M., \& Parker, D. (1995). Commonality, difference and the dynamics of disclosure in indepth interviewing. Sociology, 29(2), 241-256.

Spencer, J. (200) Ethnography after post-modernism. In P. Atkinson, A. Coffey, S. Delamont, J. Lofland, \& L. Lofland (Eds.), Handbook of ethnography (pp. 443-452). London, UK: Sage Publications.

Stacey, J. (1991). Can there be a feminist ethnography? In S. Gluck and D. Patai (Eds.), Women's words: The feminist practice of oral history. New York, NY: Routledge.

Stanley, L. \& Wise, S. (1993). Breaking out again: Feminist ontology and epistemology. New York, NY: Routledge.

Staats, C. (2016). Understanding implicit bias: What educators should know. American educator, The Education Digest, 39(4), 29-38.

Stoler, A. (1989). Making empire respectable: The politics of racial and sexual morality in twentieth-century colonial cultures. American Ethnologist, 16(4), 634-660.

Sturken, M. (1997). Absent images of memory: Remembering and reenacting the Japanese internment. Positions, 5(3), 687-707. 
Sugiman, P. (2004). Memories of internment: Narrating Japanese Canadian women's life stories. Canadian Journal of Sociology, 29(3), 359-388.

Trinh, T. Minh-Ha. (1989). Woman, native, other: Writing postcoloniality and feminism. Bloomington, IN: Indiana University press.

Twine. F. W. (2000). Racial ideologies, racial methodologies In F. W. Twine, \& J. W. Warren, (Eds.), Racing research, researching race: Methodological dilemmas in critical race studies (pp. 1-34). New York, NY: New York University Press.

Vaught, S. E. (2008). Writing against racism: Telling white lies and reclaiming culture. Qualitative Inquiry, 14(4), 566-589.

Ware. V. (1992). Beyond the pale. White women, racism and history. New York, NY: Verso. Wasserfal, R. (1993). Reflexivity, feminism and difference. Qualitative Sociology, 16(1), 2341. 